\title{
Halk Edebiyatında Taşlama: Yazıcı Murtaza Örneği*
}

\author{
Seydi KİRAZ** \\ Mustafa DEMİ***
}

\section{$\ddot{O} z$}

Yazıcı Murtaza 18. yüzyılda yaşamış Kayserili bir âşıktır. Hayatı hakkında kaynaklarda bilgi bulunmamaktadır. Müellifin Ankara Milli Kütüphane’de 06 Mil Yz A 2428 ve 06 Mil Yz. A. 4277/2 demirbaş numarası ile kayıtlı iki eseri vardır. Şair hakkında tespit edilen bilgiler bu yazmalar üzerinde yapılan çalışmalardan elde edilmiştir. Bir cizyedar kâtibi olan Yazıcı, vazifesi gereği Anadolu'dan Balkanlar'a Balkanlar'dan Basra'ya kadar uzanan geniş bir coğrafyayı gezen bir seyyahtır. Kâtipliğinin yanı sıra bir dönem müezzin ve muallim olarak görev yapmıştır. Bu çalışmada Yazıcı'nın Milli Kütüphane'de 06 Mil Yz A 2428 demirbaş numaralı eserindeki taşlamalar ele alınmıştır. Çalışmanın birinci bölümünde Türk edebiyatında eleştiriye dayalı türler açıklanmış, ikinci bölümünde de Yazıcı Murtaza'nın hayatı ve eserleri ile ilgili bilgiler verilmiş, üçüncü bölümünde ise Yazıcı Murtaza'nın taşlamaları; dil, üslup ve muhteva açısından incelenmiştir. Dördüncü bölümde de çalışmada kullanılan taşlamalar metin olarak verilmiştir. Şair bu taşlamalarda, toplumun genelinde ve memleketi Kayseri'de gördüğü olumsuzlukları anlatmıştır. Taşlamalarda dönemin siyasî, sosyal ve dinî atmosferi nükteli bazen de argoya varan söyleyişlerle dile getirilmiştir.

Anahtar Kelimeler: Yazıcı Murtaza, Âşık Edebiyatı, 18. Yüzyı1, Taşlama, Kayseri.

\footnotetext{
* Bu çalışma, Mustafa Demir'in “Sergüzeşt-i Âşık Yazıcı Murtazâ İnceleme-Metin” (Yayımlanmamış Yüksek Lisan Tezi, Hitit Üniversitesi, SBE, Çorum, 2020) adlı yüksek lisans tezinin içeriği geliştirilerek ve kısmen değiştirilerek üretilmiş halidir.

**Doç. Dr, Hitit Üniversitesi, İlahiyat Fakültesi, İslam Tarihi ve Sanatları Bölümü Türk İslam Edebiyatı Anabilim Dalı, Çorum, Türkiye.

Elmek:seydikiraz.27@gmail.com https://orcid.org/ 0000-0003-4941-3909.

*** Doktora Öğrencisi, Hitit Üniversitesi, Sosyal Bilimler Enstitüsü, İslam Tarihi ve Sanatları Bölümü, Türk İslam Edebiyatı Anabilim Dalı, Çorum, Türkiye.

Elmek: mustafademir149@gmail.com https://orcid.org/0000-0002-8180-3977.
} 


\title{
Satire In Folk Literature: Example of Yazıcı Murtaza
}

\begin{abstract}
Yazıcı Murtaza is a mistrel from Kayseri who lived in the 18th century. There is no information about his life in the sources. A. He has two works registered with the fixture number 06 Mil Yz A 2428 and 06 Mil Yz 4277/2 in Ankara National Library 4277/2. The information determined about the poet has been obtained from the studies on these manuscripts. Yazıc1, a jizya collector, is a traveler who travels a wide geography from Anatolia to the Balkans, from the Balkans to Basra, as required by his duty. In addition to his clerk, he served as a muezzin and teacher for a period. In this study, the satires in Yazicı's work with the fixture number 06 Mil Yz A 2428 in the National Library are discussed. In the first part, the types of criticism in Turkish literature are explained, in the second part, information about the life and works of Yazıcı Murtaza is given, and in the third part the satire found in the study on the poetic work has been examined in terms of form, language, style and content. In the 4th chapter, the satire quatrains used in the study are given as a text. Yazıc1 Murtaza's satire; It has been examined in terms of language, style and content. The poet explained the negativities he saw in the society in general and his hometown Kayseri in these satires. In the satires, the political, social and religious atmosphere of the period was expressed with humorous and sometimes slang.
\end{abstract}

Keywords: Yazıcı Murtaza, Minstrel Literature, 18th Century, Satire, Kayseri. 


\section{Extended Summary}

Satires; they are poems that mock and disparage. It has been said to denigrate and ridicule unapproved people, traditions and habits. In the satires, the minstre satirizes the people first, and then socializes rather than being tied to the individual. In times of strong folk tradition, satires also took on corrective tasks. Those who engage in unapproved behavior hesitated to become the talk of the minstrel.

The literature of minstrels, which gave its first works in Anatolia since the 15th century, matured in the 17th century, lived its golden age in this century and raised thousands of minstrel within the broad borders of the state. This literature, which became widespread in the public in the 18th century but could not produce an important minstrel, gained importance again in the 19th century. In the 20th century, minstrelsy lost its importance as a result of the developments encountered in social and political life (Artun 2013: 4-5). However, successful poets such as Minstrel Veysel, Minstrel Mahzuni Serif, Abdurrahim Karakoc grew up and continued this tradition in the 20th century.

In this research, answers were sought to the following questions: "Who is Yazıcı Murtaza?", "What are the works of Yazıcı Murtaza and what are the studies done on these works?", "What is the scope of the study done on Yazic1 Murtaza's work with fixture number 06 Mil Yz A 2428?", "What are the language, style and form elements used in satires? " and "What is the content of the satire found in the study?"

This study consists of introduction and four parts. In the introduction, information about the literature of minstrels and satire has been given. Then the main sections were passed.

In the first part, information is given about the types of poetry whose subject is criticism in Turkish literature.

In the second part, information about Yazic1 Murtaza's life and works was conveyed to the reader. Yazicı Murtaza was born in 1674 in the town of 
Gesi, Kayseri. There is not enough information about his family. Yazıcı worked as a jizya collector for about 15 years. During this duty, he had the chance to see different regions of the Ottoman Empire. Yazıcı has two works: 1-Prose work that includes memories of his travels. 2-The work of his poems. These works are registered in the National Library. Studies have been done on both of these works.

In the third chapter, the satire found in the study on the poetic work has been examined in terms of form, language, style and content. Yazıcı Murtaza wrote the satires in epic verse form. He conveyed what he wanted to say to the reader in direct style and in the form of advice. He used a plain language in his satires, and often included duplications and idioms. Besides, he used slang expressions in some quatrains. The subject of oppressed people, moral degradation, ignorance, and Kayseri are the subject of his satires.

In the 4th chapter, the satire quatrains used in the study are given as a text.

As a result, Yazıc1 Murtaza is a minstrel who grew up in the 18th century. Yazıc1 Murtaza revealed important information about the political, social and moral structure of the period in his satires. Among the most striking information given by the poet are the names of 106 places in Kayseri and information about the craftsmen of the period. 


\section{Giriş}

Türkler; M.Ö. 3. yüzyıldan itibaren tarih sahnesine görülmeye başlamış, bu tarihten itibaren savaşlar ve göçler nedeniyle çok geniş bir coğrafyaya yayılmış, değişik kültürlerin ve dinlerin etkisinde kalmıştır. Türkler, işaret edilen bu durumların getirdiği olumsuzluklara rağmen köklü bir edebî geleneği kurmayı başarmıştır.

Türk edebiyatı, İslamiyet'in kabulünden sonra siyasal-sosyal gelişme ve değişmelerden dolayı iki farklı biçimde şekillenmiştir: Birincisi Arap-Fars geleneklerine dayalı olarak doğup gelişme süreci içinde millîleşen divan edebiyatı, ikincisi ise Türklerin ilk millî geleneklerine bağl1 gelişen, yeni ögelerle zenginleşip çeşitlenen Türk halk edebiyatıdır (Artun 2013: 2). Bu iki edebiyat farklı biçimde şekillenmiş olsalar da onları ayrı ve faklı görmek doğru değildir. Onlar milletin ortak malıdır (Çelebioğlu 1998: 711).

Türk halk edebiyatı amaç, icra, fonksiyon ve üslup yönleriyle tekke, anonim ve âşık edebiyatı olmak üzere üç kola ayrılır. Bu üç koldan biri olan âşık edebiyatı; ilk Türk edebiyatı temsilcisi olan ozan-baksı şair tipinin ve bunların olduğu edebiyat geleneğinin, Anadolu'da tasavvufî akımlar ve tekke edebiyat1nın etkisinde de gelişmiş, İslami kurallara uygun yeni bir terkip olarak çıkmasıyla oluşan bir edebiyattır (Günay 1992: 4).

Âşık edebiyatı gelenekler içinde klasikleşmiş bir edebiyattır. Âşık edebiyatını, yalın bir dil kullanarak şiirlerini daha çok hece vezniyle yazan ve sazıyla diyar diyar gezen âşıkların eserleri meydana getirmektedir. Yaklaşık beş yüz yıllık süreç içinde Anadolu, Rumeli ve Azerbaycan'da gelişen âşı edebiyat1, çoğunlukla manzum eserlerden, bazen de düzyazı-şiir karışımı hikâyelerden meydana gelmiştir. Geniş halk tabakalarının dil ve duygu inceliğine, heyecanlarına cevap veren bu edebiyatın şairleri için genellikle "saz şairi" veya "âşı1k" ifadesi de kullanılmaktadır (Karahan 1991: 550-552).

15. yüzyıldan itibaren Anadolu'da ilk eserlerini veren âş̧ı edebiyatı, 17. yüzyılda olgunlaşmış, bu yüzyılda altın çağını yaşamış ve devletin geniş s1nırları içinde binlerce âşı̆̆ı yetiştirmiştir.18. yüzyılda halk içinde yaygınlaşan 
fakat önemli bir âş̧k ortaya çıaramayan bu edebiyat, 19. yüzyılda tekrar önem kazanmıştır. 20. yüzyılda ise sosyal ve siyasi hayatta karşılaşılan gelişmeler neticesinde âşıklık eski önemini yitirmesine (Artun 2013: 4-5) rağmen Âşık Veysel, Âşık Mahzuni Şerif, Abdürrahim Karakoç gibi başarılı şairler yetişmiş ve 20. yüzyılda bu geleneği devam ettirmişlerdir.

Âşıklar kültürel değerlerden, dinî inanışlardan, gelenek ve göreneklerden, günlük yaşamdan beslenerek şiirlerini meydana getirmişlerdir. Bu kaynakların yönlendirmesi ile halkın zevkini, beğenisini, sevincini ve acısını mısralarında dile getirmişlerdir. Bunun yanında toplumda karşılaştıkları aksaklıklar ve sorunlar da şiirlerinde yer bulmuştur. Âşıkların bu şekilde bir kimseyi yermek ya da toplumun bozuk yönlerini eleştirmek amacıyla yazdığı şiirlere taşlama denir (Dilçin 2016: 339).

Taşlama söyleme geleneği 16. yüzyılda âşıklar arasında görülmeye başlar. Özellikle Pir Sultan Abdal ve Âşık Kerem bu dönemde taşlama söyleyen âşıların başında gelmektedir. Âşık edebiyatının altın çağı olan 17. yüzyılda ise taşlama söyleyen âşıkların sayısı bir hayli artar. Âşık Ömer, Gevherî, Karacaoğlan, Kâtibi taşlama söyleyen âşıklardan birkaçıdır. Âşık edebiyatının duraklamaya girdiği 18. yüzyılda Hükmî, Mecnunî gibi âşıkların söylediği sınırlı sayıda taşlamaya rastlanmaktadır. 19. yüzyılda sürekli savaşlar, artan yoksulluk, yayılan kültürel yozlaşma ve idari boşluk neticesinde taşlamalar âşıklar arasında çok söylenmiştir. Seyranî, Dadaloğlu, Ruhsatî taşlamaları ile öne çıkan âşıklardır. 20. yüzyılda Âşık Mahzuni Şerif, Âşık Feymanî gibi âşıklar da bu geleneği devam ettirmiştir (Çıblak 2008: 71-97).

Bu çalışmada, 18. yüzyılda yaşayan, eserinde dinî, ahlakî, sosyal ve yöresel konuları ele alan Yazıcı Murtaza'nın taşlamaları incelenmiştir. Bu taşlamalar dil, üslup, şekil ve muhteva bakımından ele alınmıştır.

\section{Eleştiri Türleri}

1.1.Taşlama: Bir kimseyi veya bir varlığı yermek, kötülemek, hicvetmek için söylenen manzumedir (Banarlı 1983: 727). Tasvip edilmeyen kimseleri, gelenekleri, huyları kötülemek, onlarla alay etmek için söylenmiştir. Taşlamalarda âşık, önce kişileri ele alarak hicveder daha sonra bireye bağlı kalmayıp sosyalleşir. Halk geleneğinin kuvvetli olduğu dönemlerde taşlamalar düzeltici 
görevler de üstlenmiştir. Tasvip edilmeyen davranışlarda bulunanlar âşıkların diline düşmekten çekinmişlerdir (Güzel-Torun 2020: 316).

Taşlamalar halk şiirindeki eleştiri şiirleri olup divan şiirindeki hiciv türünün karşılığıdır. Bununla beraber taşlamalarda eleştirinin yanı sıra alay, güldürme, şaka, iğneleme gibi unsurları da görülür. Bu özellikleri taşıyan taşlamalar âşık edebiyatında görüldüğü gibi divan edebiyatında müstakil mesnevi yazan kimi şairlerin eserlerinde de görülmektedir (Kiraz 2018: 562-563).

1.2. Hiciv: Bir kimseyi yermek amacıyla yazılan şiirlere hiciv denir (Dilçin 2016: 264). Klasik edebiyatta kurum, birey ve olayların yerildiği hicivler kaside, gazel, kıta, murabba, muhammes gibi nazım şekilleriyle yazılmıştır. Bu manzumelere hicviye, hiciv yazanlara da heccâv ya da hecâ-gû adı verilmiştir (Pala-Akkuş 1998: 450).Türk edebiyatının en büyük heccâvı Nef'î'dir (Gibb 1999: 181). Onun hicivleri Sihâm-1 Kazâ adlı divanında toplanmıştır. Nefî ile beraber Şeyhî de Türk edebiyatının hiciv türünde eser veren önemli şairlerindendir. Onun Har-nâme adlı mesnevisi hiciv edebiyatının şaheserlerinden biridir (Çelebioğlu 2018: 248).

1.3.Hezl: Divan edebiyatında birinin eleştirmek ve ona yakışmayan bir şeyi söylemek üzere ahlaki teamülleri zorlayıcı biçimde söylenmiş sözlere denir. Bu adeseden bakıldığında hezl, latife ile hiciv arasında bir yerdedir. Kişiyi gülünç duruma düşürmesi bakımından hicivden daha ağır fakat küfürden ve ahlak dışı olmaktan beri olması bakımından hicivden hafif bir mizah türü olarak kabul edilmiştir (Canım 2016: 71).

\section{Yazıcı Murtaza'nın Hayatı ve Eserleri}

2.1.Hayatı: Kaynaklarda Yazıcı Murtaza adlı bir şaire ait herhangi bir bilgiye rastlanmamıştır. Şairnamelerde "Yazıcı" mahlasını kullanan bir âşı bulunmaktadır (Kaya 1990: 30). Fakat bu âşık, Saim Sakaoğlu'nun belirttiği üzere 17. yüzyıl âşıları, Âşı1k Ömer ve Gevherî’den daha önce yaşamış bir âşı olup kendinden sonra gelen bu âşılara tesir etmiştir. Bursalı olan bu şairin asıl ismi Yusuf'tur (Sakaoğlu 2014: 503). Bunun dışında Erhan Çapraz'ın Fahir Bilge'nin derlemelerinden hazırladığı eserde de iki tane Âşı Murtaza bulunmaktadır. Murtaza isimli bu âşıklardan biri Afşar âşıklarındandır ve yaşadığı 
dönem kesin olarak bilinmemektedir. Diğer Murtaza ise Afşarlar' 'n Hallı Uşağ kabilesindendir ve H.1281/M.1863 yılında doğmuştur (Çapraz 2014: 74). Eserini incelediğimiz Yazıcı Murtaza ile yukarıda isimleri zikredilen âşıkların hayatları birbirine uyuşmamaktadır. Çünkü eserini incelediğimiz Yazıcı Murtaza; Kayseri'nin Gesi kasabasında 17. yüzyılın son çeyreğinde doğmuş, 18. yüzyıl ortalarına kadar yaşamış yeni ve farklı bir şairdir. Yazıcı Murtaza H. 1084/ M. 1673'te Kayseri'nin Gesi kasabasında doğmuştur:

Gemerekde Sarıgglanda lāleyi itdim fikir ${ }^{1}$

Vațanım zaḥmenim ārzūm Gesīye geldim şükür

Ne bāg ḳalmış ne ḩod bāḳçe evim barḳım țam țaḳır

Düşlerimden geldi cümle hep bu düşmānlık baña $(8 / 56)^{2}$

Hicretiñ biñ seksen dördi velādet tārīhi oldı

Zevāli var her eşyānıñ naz̧ar ḳıl günilen aya

Eserinden Yazıcı Murtaza'nın bir cizyedar kâtibi olduğu anlaşılmaktadır. Yaşamının yaklaşık 15 yıllık süresini Osmanlı coğrafyasında birçok yeri gezerek geçirmiştir. Bu görevi 42 yaşında bırakmıştır. Yazıcı, cizyedarlık dışında muallimlik, müezzinlik ve çırakdarlık da yapmıştır:

Bi-ḥamdi'llāh yol açıldı Rūm ili semtlerine

Cizyedār oldı ag̉amız ḳıțịyān itlerine

Çekmeceden Boġadüşden Silivri yurtlarına

Sāḥil-i deryāya düşdüm ḩoş 1lımanlıḳ baña

Birḳaç yıl da böyle gitdi

Hudā luṭf u kerem itdi

Yaşım kırk ikiye yitdi

Mukim olmak vakti geldi

Berāt ile mü'ezzin hem

Çırakdārlık dahi oldum

Kaçan beş vaḳt girdigi dem

Bize hizmet lāzım oldı

1 Transkripsiyonda "Times Turkish Transcription" fontu kullanılmıştır.

2 İlk rakam şiirin numarasını, ikinci rakam ise dörtlük ya da beyit numarasını vermektedir. 
Şairin ölüm tarihi bilinmemektedir. Müellifin 10 Nisan 1739 tarihinde torunun ölümüne düştüğü tarih, onun hayatta olduğunu göstermektedir (Ertaş 2020: 18). Bu tarihten sonra müellifin ne kadar yaşadığı bilinmemektedir.

\subsection{Eserleri: Yazıcı'nın bilinen iki eseri bulunmaktadır:}

2.2.1.06 Mil Yz. A. 4277/2 Numaralı Yazma Eser: Ankara Millî Kütüphanede bulunan bu eser mecmua şeklinde oluşturulmuştur. 214 varak olan eser iki bölümden oluşmaktadır: 145. varaka kadar olan ilk bölümde, şairin kendi yazdığı bazı şiirler, ünlü şairlerin şiirleri, hikâye ve faydalı bilgilerin olduğu muhtelif yazılar bulunmaktadır. 145-214 arasındaki varaklarda; müellif, cizyedar kâtibi olarak gezip gördüğü yerleri, başından geçen olayları mensur olarak aktarmıştır. İkinci bölüm “Arnavutluk’tan Basra’ya 18. Yüzyılda Kayserili Bir Kâtibin Seyahat Anıları” adıyla yayımlanmıştır (Ertaş 2020).

2.2.2. 06 Mil Yz A 2428 Numaralı Yazma Eser: Ankara Milli Kütüphanede bulunan manzum bir eserdir. 40 varaktan müteşekkildir. Bir mecmuada 13 cüz olarak tespit ettiğimiz bu eserde toplam 143 manzume vardır.

Şair tarafından eserin 13 cüz olduğu ifade edilse de bu cüzlerin yeri belirtilmemiştir. Bu yüzden cüzlerin yerleri şiirlerdeki konu bütünlüğüne göre sonradan belirlenmiştir. Bu cüzlerde bulunan manzumeler ve cüzlerin bulunduğu varak numaraları aşağıdaki şekildedir:

\begin{tabular}{|c|c|c|}
\hline Cüz & Giriş & $(1 a-1 b)$ \\
\hline Cüz & Mersiyeler & $(1 b-10 b)$ \\
\hline Cüz & Şiir/Nazire & $(10 b-11 b)$ \\
\hline Cüz & Taşlama (Nasihatnâme şeklinde) & $(11 b-14 b)$ \\
\hline Cüz & Seyahatname & $(14 b-22 a)$ \\
\hline Cüz & Taşlama (Nasihatnâme şeklinde) & $(22 a-27 b)$ \\
\hline Cüz & Destan (Şehir Destanları/İstanbul) & $(27 b-30 b)$ \\
\hline Cüz & Türkü/Gazel/Destan & $(31 a-35 a)$ \\
\hline Cüz & Tarih Düşürmeler/Lugaz & $(35 a-36 b)$ \\
\hline Cüz & Kayseri /Kayseri Esnafi Destanı (Taşlama) & $(36 b-39 a)$ \\
\hline Cüz & Muammalar & $(39 a-39 b)$ \\
\hline Cüz & Müfred/Gazel/Rübai/Divan & $(1 \mathrm{a}-40 \mathrm{~b})$ \\
\hline Cüz & Şair ve Eserle İlgili Bilgiler İçeren Manzumeler & $(39 b-40 b)$ \\
\hline
\end{tabular}


Bu manzumelerin 120 tanesi aruz ölçüsü ile 23 tanesi hece ölçüsü ile yazılmıştır. Hece ölçüsü ile yazılan manzumelerin sayısı az olmasına rağmen hacimce aruz ölçüsüyle yazılan manzumelerden daha fazladır.

Eserde destan (8 adet), divan ( 2 adet), dörtlük ( 1 adet), koşma ( 1 adet), türkü (11 adet), semai ( 2 adet), gazel (14 adet), lugaz ( 1 adet), mersiye ( 3 adet), muamma (3 adet), tarih ( 6 adet), rübai ( 2 adet) müfred ( 88 adet) bulunmaktadır. Bunun yanında varağın kenarının yırtılmasından dolayı okunamadığı için tür ve şekli belli olmayan bir manzume bulunmaktadır (139 numaralı manzume).

Bu çalışmada 4.cüzde bulunan 7, 6. cüzde bulunan 9, 10. cüzde bulunan 32 ve 33 numaralı taşlamalar incelenmiştir.

\section{Yazıcı Murtaza'nın Eserinde Taşlama}

Yazıcı'nın eserinde 4 taşlama bulunmaktadır. Bu taşlamaların eserdeki yeri, başlığı konusu ve nazım biçimi aşağıdaki gibidir:

Tablo 1. Eserdeki Taşlamalarla İlgili Bilgiler

\begin{tabular}{|c|c|c|c|c|c|}
\hline $\begin{array}{c}\text { Eserdeki Şiir } \\
\text { Numarası }\end{array}$ & Başlık & $\begin{array}{c}\text { Dörtlük } \\
\text { Sayısı }\end{array}$ & Konu & $\begin{array}{c}\text { Nazım } \\
\text { Biçimi }\end{array}$ & $\begin{array}{c}\text { Hece } \\
\text { Ölçüsü }\end{array}$ \\
\hline 7 & Güft-i Yazıcı & 24 & $\begin{array}{c}\text { Toplumdaki } \\
\text { Ahlaki Sorunlar }\end{array}$ & Destan & $16^{\prime}$ lı \\
\hline 9 & Güft-i Yazıcı & 82 & $\begin{array}{c}\text { Toplumdaki } \\
\text { Ahlaki Sorunlar }\end{array}$ & Destan & $8^{\prime} l i$ \\
\hline 32 & $\begin{array}{c}\text { Tekerleme-i } \\
\text { Güft-i Der- Gesi }\end{array}$ & 27 & $\begin{array}{c}\text { Kayseri’deki } \\
\text { Yerleşim } \\
\text { Yerleri }\end{array}$ & Destan & $11^{\prime}$ 'li \\
\hline 33 & $\begin{array}{c}\text { Tekerleme-i } \\
\text { Bey' ü Şirā Der- }\end{array}$ & 18 & $\begin{array}{c}\text { Gesi'deki } \\
\text { Esnaflar }\end{array}$ & Destan & $11^{\prime}$ li \\
\hline
\end{tabular}

3.1.Yazıcı Murtaza'nın Taşlamalarında Biçim: 4 haneli bentlerden oluşan halk edebiyatının en uzun nazım biçime destan denir. Dörtlük sayısı 100 'ü geçen destanlar da vardır. Genellikle 11'li ve 8'li hece ölçüsü ile yazılır. (Dilçin 2016: 315) Genellikle koşma şeklinde olsa da mâni, nadir olsa da divani şeklinde örnekleri vardır. (Çobanoğlu 2000: 34). Destanlarda 8'li hece kullanılması taşlama türünde söylenen destanlar için geçerlidir (Çıblak 2008: 43) 
Destanlar konu bakımından sınırsızdır. Âşık her konuyu destan yapabilir. Âşık tarzı şiir geleneğinin kısa nazım biçimi (koşma) ile oluşturulan konuların yanında eda veya anlatım tutumu ve ezgiye göre koçaklama, taşlama, güzelleme, methiye ve ağıt olarak adlandırılan alt türlerin tamamının destan biçimi vardır (Çobanoğlu 2000: 335).

Yazıcı'nın eserinde bulunan 4 taşlama da destan nazım biçiminde yazılmıştır. Taşlamalardan iki tanesi 11'li hece ölçüsü ile yazılmıştır:

Şilmeze vü Gergin hem K̦abaḳ Dede

Maraşak Ṭıravşın Șușuz nirede

Puṣadlı Fırahtin Sümenginede

Huāke yeksān olsın daşı ḳayası

Diñleñ alışviriş iden gāāziler

Size diyem șaǵlam müşterīleri

Ben acıdım yürecigim sızılar

Aḳbabadur ugurursuzlarıñ pîri

Taşlamalardan bir tanesi 8'li hece ölçüsü ile yazılmıştır:

Elā ey ehl-i zamāne

Nedür sizde bu rezālet

Şüpheñiz var mı imāna

İtmeñ İslām'a ihānet

Taşlamaların bir tanesi de 16'lı hece ölçüsü ile nazmedilmiştir. 16'lı hece ölçüsü ile destan yazmak sık görülen bir durum değildir:

Kelām-1 Ḥaḳk söylersen bizi żemm eyledi dirler

Çok șug̉ra-kübrā ḳurarlar dimedügiñ didi dirler

Darılurlar saña bir gün bu șavmını yidi dirler

Bunuñ bog̉azına ḳurşun aḳıtmaḳ pek ' adāletdür

Yazıcı Murtaza'nın Taşlamalarında Dil ve Üslup: Üslup "kişiyi başkalarından ayıran tarz, eda ve davranış" anlamında kullanılmaktadır. Edebiyatta üslûp duygu ve düşünceleri ifade etme şekline, kelimelerin seçiminden onların terkibine, cümle ve paragraflar haline gelişine, söz ve yazı sanatlarıyla günlük 
dilin dışına çıkmasına denilmektedir (Kahraman 2012: 387). Yazıcı Murtaza gerek âşı edebiyatının gerekse divan edebiyatının üslup özelliklerini şiirlerinde kullanmıştır. Âşık edebiyatı divan edebiyatından farlı görünse de ikisi de aynı kaynaktan beslendiği için bu durum garipsenmemelidir (Kurnaz 2005: 166).

Yazıcı Murtaza; kullandığı yerel kelimeler ile atasözü ve deyimleri kullanış1; imgeleri, hayalleri, sade ve içten söyleyişi; kafiye, redif ve ayaklarla sağladığı ahengi ile nevi şahsına münhasır bir şair olarak görünmektedir.

Şairin taşlamalarında kullandığı kelime kadrosu işlediği konuya göre değişmiştir. Yazıcı, din adamlarını eleştirirken dini kavramları, esnafları eleştirirken alışveriş terimlerini kullanmıştır. Bazı dörtlüklerde "uç, sag̉ış, ığranmak, bil" (Dilçin 2018: 228, 189, 121, 44) gibi arkaik kelimelere de yer vermiştir. Yeri geldiğinde de argo tabirlere yer vermekten de çekinmemektedir:

İmāmlar cami` den bezdi

Mü'ezzinler yolı azdı

Hुalḳ bir gayri țariḳ düzdi

Fırḳa firḳa oldı cemā`at

Emir İmām egri țarike gitdi

'Ömrinde bir pāre bāzārlık itdi

'Āḳıbeti'l-emir anı da yutdu

Gülmesin dünyāda oldukça diri

Birikir hep avārālar

Anıñ yanına varalar

Cevāb dirken kavaralar

Ya'nī kim eyler nezāket

Gömeçlide vardur birḳaç uguursuz

Firiḳde var bir'ki yüzleri nûrsuz

Bürüngüzli Deli Mehemmed ' $1 r s ı z$

Borç ucundan terk eyledi diyâr1 


\subsection{Yazıcı Murtaza'nın Taşlamalarında Kullandığı Anlatım Şekilleri}

3.3.1. Doğrudan Anlatım: Yazıcı Murtaza zalimlere hitap etmek ve sofilerin hallerindeki değişikliğe dikkat çekmek için doğrudan anlatımı tercih etmiştir:

Behey zāāim hiç ölmeñ mi

Dīvānu'llâha gelmeñ mi

Su'āl var ḳabri bilmeñ mi

Nedir sende bu cesāret

Saña n'oldı behey șūfi

Fikr idüp eyle inșāfı

Kıllagör ḳalbiñi șāfi

Bilinsiñ sende kemālāt

3.3.2. Nasihat ve Hitapla Anlatım: Âşıklar taşlamalarında konu edindikleri dinî, ahlakî ve içtimaî meselelerde halkı uyarmak ve doğru yolu göstermek amacıyla nasihat ve hitap etme yoluna giderler. Yazıcı Murtaza da taşlamalarında bu anlatım biçimini kullanmıştır. Aşağıdaki dörtlükte şair, dost bildiklerinin yaptıklarını hicvederken mala ve mülke güvenmemeyi de nasihat etmektedir:

Yâr-1 gāār ola șanursın heves eylersin aḥbāba

Saña yār olmayup āḩir düşürürler iżțrāba

Dayanma leşkere māla dahı evlād u ensāba

Āhiri cümle fenādur hemān bir ḳurı gayretdür

3.3.3. Tahkiye Yoluyla Anlatım: Âşıklar, taşlamalarında yaşadıkları ya da müşahit oldukları meseleleri hikâye şeklinde anlatma yoluna gitmişlerdir.

Yazıcı Murtaza da taşlamalarında bu anlatım şeklini kullanmıştır:

Mücedded bir țarīk döndüñ

Hualḳıñ ‘ aḳāyidin bozduñ

Ḩayli mühmel işde gezdiñ

Ya'nī kim itdiñ metānet 


\subsection{Yazıcı Murtaza'nın Taşlamalarında Kullandığı Anlatım Kalıpları}

3.4.1.İkilemeler: Yazıcı, anlatımı pekiştirmek için kimi zaman ikilemelerden yararlanmıştır. Kullandığı ikilemeler Yazıcı Murtaza'nın uslubuna canlilık kazandırmıştır:

Bu cihāna ḥükm idenler

Taht u tāc ḳoyup gidenler

Hâk olan nāzīk bedenler

Saña yitmez mi ' alāmet

İki ẓālim yavrısı var yanında

Ṭemreler oḳlag̉ılanmış teninde

Dilerem hord hord hordlasan sininde

Bir șamān çöpüne șaymaz oları

3.4.2. Deyimler: Yazıc1, anlatımı zenginleştirmek, duygu ve düşüncelerini kısa fakat etkileyici şekilde göstermek için deyimleri sıklıkla kullanmıştır:

Belki gāâil ecel irer tedārigin gör irkenden (7/6)

Bir iş düşüp emân dirseñ kulak virmezler söziñe

Getürür yükledür saña göñülcügüñ alır almaz

Emek virip özendigiñ

Görenler hayretde kald1

Meylini dünyāya virmiș

Arka virdi çok 'āḳıllar

Katı hadden așdı bunlar

İsbițün pek azġin geçecek yire

Keyḳubād Maşadın degmez bir pulı

Ben acıdım yürecigim sızılar

3.4.3. Kargışlar: Kargış, hitap edilen kişi, olay ya da varlığın kötülüğünün istendiğini belirten söz kalıbıdır (Çıblak 2008: 62). Yazıcı; yaşadığı veya müşahit olduğu olaylara karşı öfkesini, hırsını ve mücadelesini bu şekilde göstermiştir: 
Hı̣ẓ ide Mevlā şerrinden

Ședāsı gelsün derinden

Yandik zehir sözlerinden

$\underline{\text { Sinine dolsun necāset }}$

İstefene Endirlik hem Zincidere

Ag gcakaya ile İleveniñ yire gire

Talasa köy dinmez beñzer bir şehre

Lākin derûnında çoḳdur kusdāsı

Bir `azīim belāda Eyyūb gelini

Merkeb arıları șoksun dilini

Bir zāg virdi dutdum dere yolunı

Küpe binmiş ḳamçı itmiş bir mārı

\subsection{Yazıcı Murtaza'nın Taşlamalarında Söz Sanatları}

İfadeye zenginlik katmak, anlatımı güçlendirmek gibi amaçlarla kullanılan ifadelere edebi sanat denir. Yazıcı Murtaza taşlamalarında telmih, teşbih, başta olmak üzere birçok edebi sanatı taşlamalarında kullanmıştır.

3.5.1. Telmih: Geçmişte bilinen bir olayı, kişiyi ya da inancı anımsatmaktır. Yazıcı aşağıdaki dörtlükte İran hükümdarları "Dârâ ve Cem”e telmih yapmıştır.

Salțanat tācın giyenler kimi Dārā kimi Cemdür

İşde geldim gider oldum gülmedim gözlerim nemdür

$\mathrm{Bu}$ anadan gidenlerden murād alup giden kimdür

Var ise evḳāt-1 ḩamse hạàżr olan cemā' atdür

Aşağıdaki dörtlükte ise Hacı Bektaş'a telmihte bulunulmuştur:

Șarı Begin og̉ı ḳalpdür ziyāde

Deli göñül hiç bulunmaz dünyāda

İki pāre nedür hey Kāḍız̄de

Pīim Hācı Bektāş Velīniñ cārı

3.5.2. Nidâ: Şairin duygulanmasına sebep olan o durumları ve varlıkları düşünüp “ey, hey” gibi ünlemlerle onlara seslenmesidir: 
Elâ ey ehl-i zamāne

Nedür sizde bu rezālet

Şüpheñiz var mı imāna

İtmek İslām'a ihânet

3.5.3. İstifham: Cevabı bilinen bir konuyu soru şeklinde söylemeye istifham sanatı denir. Bu sorulan soru dikkat çekmek için kullanılır:

Behey zālim hiç ölmeñ mi

Divanu'llāha gelmeñ mi

Su 'āl var kabri bilmeñ mi

Nedir sende bu cesāret

3.5.4.İktibas: Anlamı kuvvetlendirmek için âyet, hadis ya da bunlardan bölümler almaya denir. Aşağıdaki dörtlükte geçen "Habli'l-metîn” sağlam ip manasına gelmektedir. "Hep birlikte Allah'ın ipine sımsıkı tutunun." (Al-i İmSen mustaḳime gitseñ ne

Habli'l-metīni țutsañ ne

Hāṭ̂rı şöyle atsañ ne

İdüp Mevlāya itậ‘ at

3.5.5. Teşbih: Sözü daha etkili bir duruma getirmek için aralarında türlü yönden ilgi bulunan iki şeyden benzerlik bakımından güçsüz durumda olanı üstün olana benzetmektir. Şair aşağıdaki dörtlükte döneminde yaşananları "tilki oyunu"na benzetmiştir:

Böyle buldurmış șuyunı

Tüleyip dökmiş tüyüni

Ortalık dilkü oyunı

Anınçün yoḳdur lețāfet

3.5.6. Tarih Düşürme: H.1084 /M.1673 doğumlu şair aşağıdaki dörtlükte 53 yaşına geldiğini bildirerek H.1137/M.1724 yılını işaret etmiştir:

Sinni elli üçe yitdi

Gel gör imdi gine n'itdi

'Aceb ușlanmadı gitdi

Çekildi bunca şe'āmet 
3.5.7. Tezad: İki düşünce, duygu veya hayal arasındaki zıt durumları beraber söylemeye denir. Birbirine zıt durumları göstermek de tezad sanatına girer.

Zengin olursañ yazarlar

Zügürd olursañ bozarlar

İhtiyâr iseñ bezerler

S1kilet olursiñ bi-ḡāyet

3.5.8. İsti’âre: Bir sözcüğün kendi anlamının dışında aralarında farklı yönlerde benzerlik ilişkisi olan başka bir sözün yerine kullanılmasıdır. Aşağıdaki beyitte şair sözlerini "dürr-i meknun” olarak belirterek istiare yapmıştır.

Varırsañ meclislerine hạș1l olur periş̧ānlık

Yüziñe bile baḳmazlar ḳande ḳaldı āşinālık

Dürr-i meknūn söyleriseñ gelür anlara yeġşaḳlıḳ

Birbirine göz iderler şunı șavmaḳ żarāfetdür

\subsection{Yazıcı Murtaza'nın Taşlamalarında Muhteva}

Âşıkların taşlamaları daha çok yakınma türündendir. Toplumda bozulmalar oldukça âşıkların şiirlerinde bunlar işlenir. Önceleri felekten yakınan âşık, toplumsal bozulmalar arttıkça kuralları bozanlara yönelir. Şiirlerde konular genellikle toplumun ve devletin aksayan yönleri olur (Artun 2019: 175). Yazıcı Murtaza da eserindeki dört taşlamadan ikisinde toplumun genelindeki bozuklukları anlatır. Diğer iki taşlamanın birinde memleketi olan Kayseri'deki yerleşim yerlerinde, diğerinde de Kayseri esnafinda görülen ahlakî bozuklukları ele alır.

Şair, âşıkların genel özelliği olan "zulme karşı olma” hasletini taşlamalarına yansıtmış, mazlumlara yapılanları dile getirmiş̧ir. Bunun yanında makam mevki peşinde koşanları, toplumdaki cahilliği, din adamlarının yanlışlarını ve ahlakî problemleri şiirlerinde dile getirmiştir. Müellifin eserinde işlediği başlıca konular şunlardır:

3.6.1. Mazlumlar: Yazıcı "insanların maddi çıkarlar için dostluk yaptığını, fakirlerin itibar görmediğini, mazlumların haklı olsalar da ezildiğini, 
kâfirlerin Müslümanlardan daha değerli görüldüğünü ve mazlumların herkes tarafından hor görüldüğünü dile getirmiştir:

Eger varlı̣̣ bilürlerse dostlı̣ iderler yüzine

Ve ilā şöyle bildim ki ḳoruḳ virmezler gözüñe

Bir iş düşüp emān dirseñ ḳulaḳ virmezler söziñe

Merḥamet ref' oldı ḩalḳdan āyā bu ne 'alāmetdür

Bilürler çünki maẓlūmsın binerler başıñ üstine

Huușșateynin șarḳıdırlar iner tā ḳaşıñ üstine

Ug̉ramaḳ dahi yigdür böyle ḳallāşıñ üstine

Ḳismetiñ andan ise de giri durmak sa āadetdür

Evsaṭ ḥāllüye bu aḥvāl esfeli hiç gözi görmez

Çaġırı çaġırı olsa anınçün bir fülūs virmez

Bizde bir dīnsiz var ise bir şey andan esirgenmez

Tefekkür eyle ey gaāfil bunlar saña çok ibretdür

Bir zāalim bir depme urur bir maẓlūma yüzin düşer

O d̦arp aña yiter iken birḳaçları daḩı üşer

Arḳa arḳaya virirler hā deperler üçer beşer

Bir milletde bu iş olmaz z̧ālim bu ne 'adāvetdür

Ayrıca Yazıcı, fakirliğin kötü görülmesinden, acımasızlığın yiğitlik olarak tanınmasından, zalimlerin işlerini zor kullanarak yaptırmasından ve yiğitlerde şecaat duygusunun kaybolmasından rahatsızdır:

$\dot{Z} \mathrm{a}^{c}$ if itdi dini varlık

Zügürtlük gūyā murdārlık

Yigitlik şimdi gaddārlı̣

Fend ile eyler ticāret

Kendilere gelse bir ḥāl

Birikir cümlesi der-ḥāl

Tezkireler idüp irsal

İderler yüz biñ şefā' at 
Bir zāalim teklīf buyurur

Dutmaz ise birḳaç urur

Başın eger baḳar durur

Yigitlerde yok şecāe at

Şair, halkın zulümden yıldığını, halkta artık şenlik kalmadığını mahzun bir şekilde dile getirir:

$\operatorname{Ri}^{c}$ àya yandı yaḳıldı

Şenlik țag̉lara çekildi

Zulumden dünyā yıḳıldı

Kalmadı ḩalkda şetāret

3.6.2. Makam ve Mevki Peşinde Koşanlar: Yazıcı insanların makam ve mevki için dini kullanmasından, muttaki görünüp yalan şehadette bulunmasından, makam mevki için birbirlerini arkasından konuşup düşmanlık yapmasından muzdariptir:

Manșıb sevdāsı serinde

Üç beş yüz tesbih eliñde

Cübbe destārı̃̃ yirinde

Her yiriñ zāhid ḳıyāfet

Her biriñ müttaḳi geçer

Baklava yir ḳahve içer

Belī buyur diyüp nā-çār

İtmeli yalān şehādet

İki yaña daḩı oynar

Fesād bulgur gibi ḳaynar

Birbiriniñ etin çiyner

Eñseden eyler 'adāvet

3.6.3. Cahillik: Yazıcı, halkın ilmihal bilgisinin olmadığına ve dini öncelemediğine işaret eder. Halkın ilmihal bilgisinin eksikliğinden ve ilme liyakatsizlikten bahsederken "Türk”ten söz etmesi dönemi için dikkat çekici bir husustur. Eleştirilerini sıralarken toplumun ilme liyakatinin olmadığına, Kur'an’a 
kayıtsız kalındığına, insanların yanlış yola saptıklarına ve vaizlerin nasihatlerinin duyulup kalbe konulmadığına değinir:

Belī buyur dimeyince bunlarıñ yüzleri gülmez

Nehy-i münker eyler isen buġż idib keyfleri gelmez

' İlm-i hâlinden șorarsañ biri bilür biñin bilmez

Kayırmazlar dini așlā hep işleri bețāletdür

Türk ' ilm-i hālini bilmez

Bilenler söylese olmaz

' İlim meclisine gelmez

Dir ki bende yoḳ liyāḳat

Bilenler böyle itmezdi

Huilāf țarịke gitmezdi

Kur'ān hüükmin unutmazdı

Meger itmezler tilāvet

Vāc iẓiñ nusḥını duymaz

Duyar ammā kalbe ḳoymaz

Kendiniñ de fi ' li uymaz

Anda da vardur kesālet

3.6.4. Ahlakî Sorunlar: Yazıcı Murtaza'nın taşlamalarında yer verdiği konulardan biri de toplumda yaşanan ahlakî yozlaşmadır. Livatanın yaygınlaşması, 1rz ve namus tanımayanlar, gençlerin milletin namusuna göz dikmeleri, yaşlılardaki ahlaksızlıklar eleştirilmiştir:

Kavm-i Lūtı geçdi bunlar

Katı ḥadden aşdı bunlar

Fesād bābın açdı bunlar

İşleri cümle betālet

Yanıp gider faḳirü'l-hāl

Görür anı ider ihmāl

Nedür bilmez ' 1 rż u vekār

Yoḳdur a' yānda mehābet 
Niçe yārānları gördüñ

Bunlar ḳardaş olmış dirdiñ

Șoñra neticeye irdiñ

'Irżını itmiş kesāret

Deliḳanlıca uşaḳlar

Șiyirdip gezer șoḳaḳlar

Ehl-i ' rrżı̃ adın yoḳlar

Yapar yoḳ bulur selāmet

Dört beş yaşlı ḥayā bilmez

Söyleseñ sözüñden almaz

Birkaç sille çalsañ olmaz

Șāhibinde yoḳ șadāḳat

3.5.5. Din Adamlarındaki Bozulma: Yazıc1, imamların camiden bıkt1ğını, müezzinlerin yoldan çıktığını bu yüzden de halkın parça parça olduğunu, yeni çıkan yolların halkın akaidini bozduğunu, sufilerin hallerinin değiştiğini, insanların âlimleri değil mülhitleri ziyaret etmesini eleştirmiştir:

İmāmlar cāmi` den bizdi

Mü' 'ezzininler yolı azdı

Halk bir gayri țarīk düzdi

Fırḳa firḳa oldı cemā`at

Mücedded bir țarīk döndüñ

Halḳıñ 'akāyidin bozduñ

Huayli mühmel işde gezdiñ

Ya'nī kim itdiñ metānet

Saña n'oldı behey șūfi

Fikr idüp eyle inșāa

Ḳ1lagör kalbiñi șāfi

Bilinsiñ sende kemālāt 
'Ālime gelsiñ er ise

Bāg $\dot{g}-1$ cennet ister ise

Nirde bir mülhiid var ise

İderler anı ziyāret

3.5.6. Esnaflar: Yazıcı Murtaza, "Tekerleme-i Bey` ü Şirā Der-Gesî̀” başlıklı ve 18 dörtlükten oluşan destanda, Kayseri esnafını eleştirmiştir. Eleştirilerde esnaf isimlerini ya da lakaplarını vermiş ve onların olumsuz özelliklerini dile getirmiştir. Şair, destanda sadece bir esnafın olumlu özelliğinden söz etmiştir.

Manzumeye sağlam müşterilerden söz ederek başlar. İlk dörtlüğün son mısraından itibaren esnaf ve onların olumsuz özelliklerini dile getirmeye başlar:

Diñleñ alışviriş iden gâziler

Size diyem șag̉lam müşterīleri

Ben acıdım yürecigim sızılar

Aḳbabadur ug̉ursuzlarıñ biri

Yazıcı esnafın bir kısmının sadece bir olumsuz özelliğini vererek yermiştir. Bu kişiler aşağıdaki tabloda verilmiştir:

Tablo 2. Taşlamada Bir Tane Olumsuz Özelliği Verilen Esnaf

\begin{tabular}{|c|c|}
\hline Esnafin Adı ya da Lakabı & Hicvedilen Özelliği \\
\hline Seydaḥmedog் ${ }_{1}$ & misli bulunmaz \\
\hline Hasan Day1 & virilen alınmaz \\
\hline Eyyūb gelini & Bir'azīim belā \\
\hline Kara Ḧüseyin & belānıñ büyügi \\
\hline Șarıc'og̉1 & yüzler ḳarası \\
\hline Șar1 Begin oġl & ḳalpdür ziyāde \\
\hline Koca 'İvaż & kalpāzānlarıñ pīiri \\
\hline Mazıcı-zāde & Aldiġını virmez \\
\hline Köse 'Ali Dede & çürükden çürük \\
\hline Bürüngüzli Deli Meḥemmed & '1rs1z \\
\hline Cerrār & aldıġın virmez \\
\hline
\end{tabular}

Kimi zaman bir esnafın birden fazla olumsuz özelliği birkaç mısrada verilmiştir: 
Ḥelvacı torunı gitdi Mıṣıra

'Ali Dayım bizi sardı hasıra

Boynumuz egmeden döndük esīre

Ferāgat itmemiz yigdür buları

Şair bazı dörtlüklerde esnaf ismini vermek yerine onların bulundukları yeri söyleyerek onların taşlamıştır:

Gömeçlide vardur birḳaç ug̉ursuz

Firiḳde var bir'ki yüzleri nûrsuz

Bürüngüzli Deli Mehemmed ‘ārsız

Borç ucundan terk eyledi diyārı

3.5.7. Yerleşim Yerleri: Müellif “Tekerleme-i Güft-i Der-Gesī” başlıklı şiirinde Kayseri’yi öven 4 dörtlükten sonra Kayseri'de bulunan yerleşim yerlerini hicveder. Şair bu şiirde Kayseri'de bulunan 106 yerleşim yerinden (Sürütme, Ḳızılvirān, Ḥacılar, Şeyh Çoban, İnceșu, Ḥișārcıḳ, İsțefene, Endirlik, Zincidere, Aġcaḳaya, İleve, Talas, Germirli, Kumarlı, Cırḳalan, İsbiṭün, Cırlavıḳ, Dimidire, Nīzeniñ, İrtāng1, İfkere, Dārsiyāk, Bürüngüz, Bālā Gesīi, Telaṣıra, Șalḳuma, Gergere, Dikiri, Küstere, Kamber, Șaḳaldutan, Çevlik Süleymānlı, Vengicek Köpez, Sardın, Şilmeze, Gergin, Kabaḳ Dede, Maraşaḳ Țıravşın Șuṣuz, Pușadlı, Furahtin, Sümengine, Șarı Meḥemmedli, Yamaçlı, Kömür, Ṭomārza, Şeyh Barāk, Vekse, Aġırnas, İskübü, Bürüngüz, Sābr, Miṣāḳlı, Gergeme, Gömeç, Barșama, Șarāycıḳ, Karaḳaya, Yag̉murbeg, Kemrelik, Çuḳurküpeli 'İmāret, Ḳuzcag̉ız İyimḳıñış Höbek İsli ' Ayālı, Obruḳ Ḥancı, Kuş̧cı, Ceviril, Mālhāè, 'Ammiler, Ṭaşān, Ebiş, Boyacı, Hurhāāl, Gemere, Dadag̉ı, Melzemin, Kara Mehememedli, Muncūsın, Ḳızıḳlı, Hörgüçli, Karayük, Șalur, Aġın, Ḥasan Alp, Yazır, Dadasın, Kilḥacı, Erkilet, Arḳıncıḳ Elagöz, Yorkadıñ, Keyḳubād, Maşadın, Anbara, Molı Yuvalı, Kırḳpıñār, Bayrâm Ḥācı, Gesī) olumlu veya olumsuz şekilde bahseder. Bu yerleri hicvettiğini şiirinin sonunda şöyle belirtir:

Hicv olan köylerde ne cānlar da var

Anlara söz yoḳdur lāḥiḳ olmaz ‘ ār

'İrfānı olanlar me ’āli añlar

Böyle olmayınca gelmez imlāsı 
Şair Erciyes Dağı'nı dağların sultanı olarak tavsif etmiş ve Yalınızgöz isimli köprü bulunduğunu belirterek Kayseri'den övgüyle söz etmiştir:

Dağlarıñ sulțānı Erciyes sende

Hiç mișli bulunmaz Hindde Yemende

Yalıñıgöz iki köpri var ḳande

Bir yüce bil gibi durur arkası

Yazıcı daha sonra Kayseri'nin ilmin durağı ve halkının âlimlerin çırağı olduğunu dile getirerek Kayseri'yi övmeye devam eder:

Bir şehr-i a' żamdur 'ilmiñ duraġı

Ekșer ḩalḳı bir ' allāmıñ çerāg̀ 1

Bahārın açılur bostānı bāğı

Maḥbūblarla tezyīn olur șaḥrāsı

Şair övgüsünü bitirdikten sonra "Dinle imdi bu garibin pendini" diyerek köyleri hicvetmeye başlar. Mezkûr mısradan hareketle şairin hicvetme amacının öğüt vermek olduğu anlaşılmaktadır:

Ufaḳ dağlar iḥāta itmiş kendini

Diñle imdi bu garīibiñ pendini

Biraz söyleyelim köyin kendini

Herkesiñ bir şeyde vardur sevdāsı

Yazıcı dörtlüklerde birden çok yerden bahsetmiştir. Aynı dörtlükte 3 yeri hicvederken bir yeri de övmüştür. Aşağıdaki dörtlükte Mancusın için "hoş" tabirini kullanan şair, İsbitün'ün pek azgın, Cırlavık ve Dimidre'de şerlilerin meskûn olduğunu dile getirmiştir:

Muncūsın bir ḩoşdur varanlar göre

İsbițün pek azġın geçecek yire

Biri de Curlavık hem Dimidire

Bunlar durur eşirrānı̃ süknās1

Şairin köylere karşı tutumunda ona karşı köylülerin takındıkları tavrın etkili olduğu da anlaşılmaktadır:

Bize bir ḩoş geldi Muncūsın köyi

Bir miḳdārca iḥsān itdiler diyi 
Kıı1ḳlı Hörgüçli bir ḳarış tüyi

Zıır ẓır añırırlar Haḳdan bulası

Yazıcı Murtaza bazı köylerin ortadan yok olmasını bile ister. Bu durumun yukarıdaki dörtlükte belirtilen şahsi husumetten kaynaklandığı muhtemel gözükmektedir:

Şilmeze vü Gergin hem Kabaḳ Dede

Maraşaḳ Ṭıravşın Șuṣuz nirede

Puṣadlı Frrahtin Sümenginede

Ḩāke yeksān olsın daşı ḳayası

Müellif, köyleri Alevî-sünnî olarak da belirtmiştir. Gömeçli’nin Müslüman imamı sevmediğini belirtir. Hırhalı'nın ise kızılbaştan taç giydiğini dile getirir:

Gömeçli Müslimān imāmı sevmez

Barșama Șarāycık ẓırvā da bilmez

Bileñ köyleri de şenlige gelmez

Karaḳayadur anları̃ yaylası

Hancı ve Kִuşcı Ceviril Mālhạàı

'Ammilerle Ṭaşān Ebiş Boyacı

K1zılbașdan geymiș Hurhāli tāc1

Gemereyle Dadag்ınıñ arası

Şair, kendine göre başka yerlerde de gördüğü olumsuzlukları da dile getirir. Şiirin en son dörtlüğünde ise kendi köyü olan Gesi'ye övgüler dile getirerek sözüne son verir:

Cümleden Gesīdür cennet mis̄āli

$\bar{A}$ b u havâsı hūb hem ḳadri ' àli

Ahālīsi bilür erkānı yolı

Yazıcıdur cümlesinin ednāsı 


\section{Metin}

1 Saltanat tācın giyenler kimi Dārā kimi Cemdür

İşde geldim gider oldum gülmedim gözlerim nemdür

$\mathrm{Bu}$ anadan gidenlerden murād alup giden kimdür

Var ise evḳāt-1 ḩamse ḥāżır olan cemā‘ atdür

2 Yâr-1 gāār ola șanursin heves eylersin aḥbāba

Saña yār olmayup āḩir düşürürler iżțrāba

Dayanma leşkere māla dahı evlād u ensāba

Āhiri cümle fenādur hemān bir ḳurı gayretdür

3 Eger varlıḳ bilürlerse dostlıḳ iderler yüzine

Ve ilā şöyle bildim ki ḳoruḳ virmezler gözüñe

Bir iş düşüp emān dirseñ kulaḳ virmezler söziñe

Merḥamet ref' oldı ḩalḳdan āyā bu ne ' alāmetdür (7/11)

4 Varırsañ meclislerine haș̣1 olur perīşānlık

Yüziñe bile baḳmazlar ḳande ḳaldı āşinālık

Dürr-i meknūn söyleriseñ gelür anlara yeggşaḳlıḳ

Birbirine göz iderler şunı șavmaḳ żarāfetdür

5 Kelām-1 Ḥaḳkı söylersen bizi zemm eyledi dirler

Çok șugira-kübrā ḳurarlar dimedügiñ didi dirler

Darılurlar saña bir gün bu șavmını yidi dirler

Bunuñ boġazına ḳurşun aḳıtmaḳ pek ‘ adāletdür

6 Bilürler çünki maẓlūmsın binerler başıñ üstine

Husușateynin șarḳıdırlar iner tā ḳaşı̃̃ üstine

Ug̉ramaḳ dahi yigdür böyle kallāş̧ñ üstine

Ḳısmetiñ andan ise de giri durmaḳ sa' ādetdür

7 Bir zāalim bir depme urur bir maẓlūma yüzin düsşer

O ḍarp aña yiter iken birḳaçları dahı üşer

Arḳa arḳaya virirler hā deperler üçer beşer

Bir milletde bu iş olmaz ẓālim bu ne ' adāvetdür 
8 Evsat hāāllüye bu aḥvāl esfeli hiç gözi görmez

Çaġırı çaġırı olsa anınçün bir fülūs virmez

Bizde bir dīnsiz var ise bir şey andan esirgenmez

Tefekkür eyle ey ġāfil bunlar saña çok ibretdür

$9 \quad$ Elā ey ehl-i zamāne

Nedür sizde bu rezālet

Şüpheñiz var mı imāna

İtmeñ İslām'a ihanet

10 Behey zālim hiç ölmeñ mi

Dīvānu'llâha gelmeñ mi

$\mathrm{Su}$ 'āl var ḳabri bilmeñ mi

Nedir sende bu cesāret

11 Manșıb sevdāsı serinde

Üç beş yüz tesbih eliñde

Cübbe destārıñ yirinde

Her yiriñ zāhid ḳıyāfet

12 Her biriñ müttaḳi geçer

Baklava yir ḳahve içer

Belī buyur diyüp nā-çār

İtmeli yalān şehadet

13 Sen mustaḳime gitseñ ne

Habli'l-metīni țutsañ ne

Ḩāṭırı şöyle atsañ ne

İdüp Mevlāya ițāc at

14 Mücedded bir tarīk döndüñ

Halkı̣ı̃ ‘ aḳāyidin bozduñ

Hayli mühmel işde gezdiñ

Ya' nī kim itdiñ metānet 
15 Bilenler böyle itmezdi

Huilāf țarị̣e gitmezdi

Kur'ān hükmin unutmazdı

Meger itmezler tilavet

16 Saña n'oldı behey șūfí

Fikr idüp eyle inșāfı

Kılagör ḳalbiñi șāfi

Bilinsiñ sende kemālāt

17 Yanıp gider faḳirü'l-hāl

Görür anı ider ihmāl

Nedür bilmez ' 1 rż u vekār

Yoḳdur a' yānda mehabet

18 Türk 'ilm-i hālini bilmez

Bilenler söylese olmaz

' İlim meclisine gelmez

Dir ki bende yok liyakat

19 İki yaña daḩı oynar

Fesād bulgur gibi ḳaynar

Birbiriniñ etin çiyner

Eñseden eyler 'adāvet

20 Böyle buldurmış șuyunı

Tüleyip dökmiş tüyüni

Ortalık dilkü oyunı

Anınçün yoḳdur lețāfet

$21 \quad \dot{Z} a^{c}$ if itdi dīni varlık

Zügürtlük gūyā murdārlık

Yigitlik şimdi gaddārlık

Fend ile eyler ticāret 
22 Hifz ide Mevlā şerrinden

Ședāsı gelsün derinden

Yand1k zehir sözlerinden

Sinine dolsun necaset

23 Niçe yārānları gördüñ

Bunlar ḳardaş olmış dirdiñ

Șoñra neticeye irdiñ

'Irżını itmiş kesāret

24 Niçe yārānları gördüñ

Bunlar k̦ardaş olmış dirdiñ

Șoñra neticeye irdiñ

'Irżını itmiş kesāret

25 Deliḳanlıca uşaḳlar

Șiyirdip gezer șoḳaḳlar

Ehl-i ' 1rżıñ adın yoḳlar

Yapar yok bulur selamet

26 Dört beş yaşlı ḥayā bilmez

Söyleseñ sözüñden almaz

Birkaç sille çalsañ olmaz

Șāḥibinde yoḳ ṣadāḳat

27 Bir zạalim teklīf buyurur

Dutmaz ise birḳaç urur

Başın eger baḳar durur

Yigitlerde yok şecāe at

2 Bu cihāna hükm idenler

Taḥt u tāc ḳoyup gidenler

Ḩâk olan nāzīk bedenler

Saña yitmez mi ' alāmet 
Kavm-i Lūtı geçdi bunlar

Katı hadden aşdı bunlar

Fesād bābın açdı bunlar

İşleri cümle betālet

30 ' $\bar{A}$ lime gelsiñ er ise

Bāg-1 cennet ister ise

Nirde bir mülhid var ise

İderler anı ziyāret

31 İmāmlar cami` den bizdi

Mü 'ezzinler yolı azd1

Halk bir gayri țarị düzdi

Firḳa firḳa oldı cemā‘ at

32 Vāe iziñ nusḥını duymaz

Duyar ammā ḳalbe ḳoymaz

Kendiniñ de fi` li uymaz

Anda da vardur kesālet

33 Zengin olursañ yazarlar

Zügürd olursañ bozarlar

İhtiyâr iseñ bezerler

Ślḳlet olursıñ bi-gāāyet

$34 \quad \mathrm{Ri}^{`}$ āya yandı yaḳıldı

Şinlik țag̉lara çekildi

Zulumden dünyā yıḳıldı

Kalmadı halḳda şetaret

35 Birikir hep avārālar

Anıñ yanına varalar

Cevāb dirken ḳavaralar

Ya'nī kim eyler nezāket 
$36 \quad$ Sinni elli üçe yitdi

Gel gör imdi gine n'itdi

'Aceb uṣlanmadı gitdi

Çekildi bunca şe'āmet

37 Dag̉larıñ sulțānı Erciyes sende

Hiç misli bulunmaz Hindde Yemende

Yalıñıgöz iki köpri var ḳande

Bir yüce bil gibi durur arkas1

38 Bir şehr-i a' żamdur ' ilmiñ durağ1

Ekșer ḩalḳı bir ' allāmıñ çerāğ 1

Bahārın açılur bostānı bāğı

Maḥbūblarla tezyīn olur șaḥrāsı

39 Ufaḳ dag̉lar ihăăta itmiş kendini

Diñle imdi bu garīibiñ pendini

Biraz söyleyelim köyin kendini

Herkesiñ bir şeyde vardur sevdāsı

40 İsțefene Endirlik hem Zincidere

Aggcaḳaya ile İleveniñ yire gire

Ṭalasa köy dinmez beñzer bir şehre

Lākin derûnında çoḳdur kusdāsı

41 Muncūsın bir ḩoşdur varanlar göre

İsbițün pek azġın geçecek yire

Biri de Curlavık hem Dimidire

Bunlar durur eşirrānıñ süknāsı

42 Şilmeze vü Gergin hem Kabak Dede

Maraşaḳ Ṭıravşın Șuṣuz nirede

Puṣadlı Fırahtin Sümenginede

Ḩāke yeksān olsın daşı ḳayası 
43 Gömeçli Müslimān imāmı sevmez

Barșama Șarāycı̣̣ ẓırvā da bilmez

Bileñ köyleri de şenlige gelmez

Karaḳayadur anlarıñ yaylası

44 Hancı ve Kuşsı Ceviril Mālhāè

'Ammilerle Ṭaşān Ebiş Boyacı

Küılbaşdan geymiş Ḩırhālı tācı

Gemereyle Dadag்ını̃̃ arası

45 Bize bir ḩoş geldi Muncūsın köyi

Bir miḳdārca iḥsān itdiler diyi

Kaıııḳlı Hörgüçli bir ḳarış tüyi

Zır zıır añırırlar Haḳdan bulası

46 Cümleden Gesīiür cennet mis̄āli

$\bar{A}$ b u havâsı hūb hem ḳadri 'a àli

Ahālīsi bilür erkānı yolı

Yazıcıdur cümlesinin ednası

47 Diñleñ alışviriş iden gāāziler

Size diyem șag̉lam müşterīleri

Ben acıdım yürecigim sızılar

Aḳbabadur ugiursuzlarıñ pīir

$48 \quad$ Helvacı torunı gitdi Mıṣıra

'Ali Dayım bizi șardı ḥașıra

Boynumuz egmeden döndük esīre

Ferāgat itmemiz yigdür buları

49 Bir ' azīim belāda Eyyūb gelini

Merkeb arıları șoḳsun dilini

Bir zāg virdi dutdum dere yolunı

Küpe binmiş ḳamçı itmiş bir mārı 
50 İki zālim yavrısı var yanında

Ṭemreler oḳlağılanmış teninde

Dilerem hord hord hordlasan sininde

Bir șamān çöpüne șaymaz oları

51 Șarı Begin og̉l ḳalpdür ziyāde

Deli göñül hiç bulunmaz dünyāda

İki pāre nedür hey Kāḍzāde

Pīrim Hācı Bektāş Velīniñ cārı

52 Emir İmām egri țariḳe gitdi

'Ömrinde bir pāre bāzārlı̣ itdi

'Āḳıbeti'l-emir anı da yutdu

Gülmesin dünyāda oldukça diri

53 Gömeçlide vardur birḳaç ug̉ursuz

Firikde var bir'ki yüzleri nûrsuz

Bürüngüzli Deli Mehemmed ' $1 r s 1 z$

Borç ucundan terk eyledi diyârı

$54 \quad$ Hicv olan köylerde ne cānlar da var

Anlara söz yoḳdur lāhik olmaz ‘ ār

'İrfānı olanlar me 'āli añlar

Böyle olmayınca gelmez imlası

\section{Sonuç}

Bu çalışmada kaynaklarda adı zikredilmeyen Yazıcı Murtaza adında bir âşığın hayatı ve eserleri hakkında genel bir bilgi verilmiştir. Yazıcı Murtaza'nın incelenen eserinde âşık edebiyatında kullanılan tür ve şekiller yanında divan edebiyatında s1kl1kla kullanılan gazel, müfred, tarih, muamma, lugaz gibi tür ve şekiller de görülmektedir. Özellikle müellifin eserin derkenarlarına yazdı̆̆ 88 müfred hem söyleyiş hem de muhteva bakımından dikkat çekicidir. Bu bakımdan eser, 18. yüzyılda divan edebiyatının âşık edebiyatı üzerindeki tesirini göstermesi bakımından ehemmiyet arz etmektedir. 
Çalışmada dikkat çeken hususlardan biri de şairin taşlamalarındaki muhtevadır. Taşlamalarda genellikle toplumun dinî, ahlakî ve sosyal problemleri üzerinde durulmuştur. Taşlamalardan ikisi Kayseri'yle ilgilidir: Birincisinde Kayseri'deki 106 yerleşim yeri zikredilerek eleştirilmiş, ikincisinde ise o 18 . yüzyıl Kayseri esnafı, isimleri verilmek suretiyle yerilmiştir. Bu iki taşlama, Kayseri' deki yer ve kişi isimleri ile o dönem yaygın meslekler hakkında bilgiler vermesi açısından önem arz etmektedir.

Taşlamalar, sade bir dille yazılmıştır. Anlatım ve üslup gelenekten gelen kavramlar, dinî motifler ve yerel söyleyişlerle zenginleştirilmiştir. Taşlamalarda kargışlara ve argo söyleyişlere de rastlanmıştır. Hece ölçüsüyle yazılan taşlamalarda döner ayak tercih edilmiş, kullanılan ayaklarla, uzunluğu 82 dörtlüğe varan destanlarında kompozisyon bütünlüğü sağlanmıştır. Bu özelliğinden dolay1 şair, başarılı bir âşı olarak değerlendirilebilir.

Netice olarak bu çalışmayla 18. yüzyılda yaşamış Kayserili bir âşı ve eseri ilk defa ortaya çıkarılarak istifadeye sunulmuştur. Böylece bu yüzyılda yaşamış olan Develili Seyranî, Molulu Revaî'den sonra bir başka halk şairi olan Gesili Yazıcı Murtaza literatüre kazandırılmıştır. 


\section{Kaynaklar}

Artun, E. (2013). Aş̧ı Edebiyatı Metin Tahlilleri, Adana: Karahan Kitabevi.

Artun, E. (2019). Âşılklık Geleneği ve Âşık Edebiyatı, Ankara: Karahan Kitabevi.

Banarlı, N. S. (1983). Resimli Türk Edebiyatı Tarihi (C. 2), İstanbul: Milli Eğitim Basımevi.

Canım, R. (2016). Divan Edebiyatında Türler, Ankara: Grafiker Yayınları.

Çapraz, E. (2014). Fahir Bilge Derlemeleri/Kayseri ve Yöresi Halk Şairleri, Kayseri: Talas Belediyesi Kültür Yayınları.

Çelebioğlu, A. (1998). Eski Türk Edebiyatı Araştırmaları, İstanbul: Milli Eğitim Basımevi.

Çelebioğlu, A. (2018). Türk Mesnevi Edebiyatı Sultan İkinci Murad Devri, İstanbul: Dergâh Yayınları.

Çıblak, N. (2008). Asşık Şiirinde Taşlamalar, Ankara: Ürün Yayınları.

Çobanoğlu, Ö. (2000). Aşsı Tarzı Kültür Geleneği ve Destan Türü, Ankara: Akçağ Yayınları.

Demir, M. (2020). Sergüzeşt-i Âşık Yazıcı Murtazâ, Çorum: Hitit Üniversitesi, Sosyal Bilimler Enstitüsü. (Yayımlanmamış Yüksek Lisans Tezi)

Dilçin, C. (2016). Örneklerle Türk Şiir Bilgisi, Ankara: Türk Dil Kurumu Yayınları.

Dilçin, C. (2018). Yeni Tarama Sözlüğü, Ankara: Türk Dil Kurumu Yayınları.

Ertaş, M. (2020). Yazıcı Murtaza Arnavutluk'tan Basra'ya 18. Yüzyılda Kayserili Bir Kâtibin Seyahat Anıları. Kitabevi.

Günay, U. (1992). Türkiye'de Âşık Tarzı Şiir Geleneği ve Rüya Motifi, Ankara; Akçağ Yayınları. Gibb, E. J. W. (1999). Osmanlı Şiir Tarihi II (A. Çavuşoğlu, Çev.; C. 2), Ankara: Akçağ Yayınları.

Güzel, A. \& Torun, A. (2020). Türk Halk Edebiyatı El kitabı, Ankara: Akçağ Yayınları.

Kahraman, A. (2012). Üslûp. TDV İslam Ansiklopedisi (C. 42, ss. 387-388), Ankara: Türkiye Diyanet Vakfi.

Karahan, A. (1991). Âşık Edebiyatı. TDV Íslam Ansiklopedisi (C. 3, ss. 550-552), Ankara: Türkiye Diyanet Vakfi.

Kaya, D. (1990). Şairnameler, Ankara: HAGEM Yayınları.

Kiraz, S. (2018). Süleyman Giryani Necmü'l-Kulûb (İnceleme-Metin), İstanbul: Kitabevi.

Kurnaz, C. (2005). Halk Şiiri ve Divan Şiirinin Müşterekleri, Ankara: Gazi Kitabevi.

Sakaoğlu, S. (2014). Aşsık Edebiyatı Araştırmaları, Konya: Kömen Yayınları. 